\title{
PENERAPAN MEDIA BIG BOOK DALAM MENINGKATKAN HASIL BELAJAR BAHASA ARAB KELAS IV
}

\author{
Siti Nurohmah \\ Universitas Islam Negeri Sunan Gunung Djati Bandung, Jawa Barat \\ Jl. A.H. Nasution No.105, Cipadung, Cibiru, Kota Bandung, Jawa Barat 40614 \\ email: sitinurohmahasmin@gmail.com \\ Nanang Kosim \\ Universitas Islam Negeri Sunan Gunung Djati Bandung, Jawa Barat \\ Jl. A.H. Nasution No.105, Cipadung, Cibiru, Kota Bandung, Jawa Barat 40614 \\ email: nanang.kosim@uinsgd.ac.id \\ Dede Rohaniawati \\ Universitas Islam Negeri Sunan Gunung Djati Bandung, Jawa Barat \\ Jl. A.H. Nasution No.105, Cipadung, Cibiru, Kota Bandung, Jawa Barat 40614 \\ email: dederohaniawati@uinsgd.ac.id_
}

\begin{abstract}
This study aims to determine student learning outcomes in Arabic subjects before the application of Big Book media, the process of applying Big Book media and student learning outcomes after the application of Big Book media in class IV MI Naelushibyan. The research method used is classroom action research through four repetitive stages of planning, implementation, observation or observation, and reflection. The object of research was 15 students. The research instrument consisted of a teacher activity observation sheet, a student activity observation sheet and a written test. Data collection techniques use observation and test techniques. The results obtained from this study are the learning outcomes of students in the pre cycle get an average score of 53. The first cycle obtained the average value of teacher activity $72.2 \%$ and cycle II obtained an average value of $94.4 \%$. Student activity in cycle I obtained an average value of $69.21 \%$ and cycle II obtained an average value of $91.07 \%$. Student learning outcomes in cycle I obtained an average value of 77 , cycle II obtained an average value of 83.6. It can be concluded that Big Book media can improve student learning outcomes.
\end{abstract}

Keywords: Learning Outcomes Big Book Media

\begin{abstract}
Abstrak
Penelitian ini bertujuan untuk mengetahui hasil belajar siswa pada mata pelajaran Bahasa Arab sebelum penerapan media Big Book, proses penerapan media Big Book dan hasil belajar siswa setelah penerapan media Big Book di kelas IV MI Naelushibyan. Metode penelitian yang digunakan adalah penelitian tindakan kelas melalui empat tahap secara berulang yaitu perencanaan, pelaksanaan, observasi atau pengamatan, dan refleksi. Objek penelitian sebanyak 15 siswa. Instrumen penelitian terdiri dari lembar observasi aktivitas guru, lembar observasi aktivitas siswa dan tes tulis. Teknik pengumpulan data menggunakan teknik observasi dan tes. Hasil yang diperoleh dari penelitian ini adalah hasil belajar siswa pada prasiklus mendapat
\end{abstract}


nilai rata-rata 53. Siklus I diperoleh nilai rata-rata aktivitas guru72,2\% dan siklus II diperoleh nilai rata-rata $94,4 \%$. Aktivitas siswa pada siklus I diperoleh nilai rata-rata $69,21 \%$ dan siklus II diperoleh nilai rata-rata 91,07\%. Hasil belajar siswa pada siklus I diperoleh nilai rata-rata 77, siklus II diperoleh nilai rata-rata 83,6. Dapat disimpulkan bahwa media Big Book dapat meningkatkan hasil belajar siswa.

Kata kunci: Hasil Belajar, Media Big Book

\section{Pendahuluan}

Bahasa Arab merupakan bahasa tertua dan paling lama digunakan di dunia. Sejak al-Qur'an diturunkan dan agama Islam semakin berkembang. Bahasa ini digunakan secara resmi oleh kurang lebih 20 negara. karena bahasa Arab adalah bahasa kitab suci dan tuntunan agama umat Islam sedunia. ${ }^{1}$

Bahasa Arab selain menjadi bahasa lisanjuga bahasa tulisan. Bahasa tulisan inilah yang telah menciptakan kebiasaan keilmuan di kalangan umat Islam. Secara historis dapat dibuktikan dengan karya-karya fenomenal para ulama di berbagai bidang; dibidang Tafsir, Hadits, Fiqih, Aqidah dan dibidang ilmu keIslaman lainnya tertulis dalam bahasa Arab. Karena sumber-sumber asli ajaran Islam danilmu-ilmu keIslaman tertulis dalam bahasa Arab, maka sangat penting untuk umat Islam terutama dalam dunia keilmuan atau akademisi muslim untuk mempelajari dan memahami serta menguasai bahasa Arab dalam pengembangan pendidikan Islam $^{2}$ Sistem pembelajaran modern saat ini menuntut siswa tidak sekedar bertindak sebagai penerima pesan, tetapi siswa juga berperan sebagai penyampai pesan. Dalam keadaan ini, maka timbul apa yang disebut dengan hubungan dua arah bahkan hubungan banyak arah. Dalam komunikasi pembelajaran media pembelajaran sangat dibutuhkan untuk menambah daya guna dalam mencapai tujuan pembelajaran. Artinya, proses pembelajaran akan beralangsung apabila ada hubungan antara

\footnotetext{
${ }^{1}$ Asna Andriani, "Pembelajaran Bahasa Arab" 03, no. September 2014 (2015): 39-56.

2 Andriani, 39-56.
}

penerima pesan dengan sumber/penyalur pesan melalui media tersebut.

Memasuki dunia pendidikan pada saat ini pendidikan memasuki masa dunia media. Kegiatan pembelajaran mengharuskan mengurangi metode ceramah dan diganti dengan pemakaian media. Terlebih pada kegiatan pembelajaran saat ini yang mementingkan pada keterampilan proses dan activelearning, maka fungsi media pembelajaran, menjadi semakin penting. ${ }^{3}$

Media merupakan alat bantu yang gunakan oleh guru dalam proses belajar mengajar. Media digunakan guru untuk menyampaikan pesan-pesan dari bahan pelajaran yang akan diberikan kepada siswa. Tanpa dukungan media, pelajaran akan sulit diterima oleh siswa, terutama pada pelajaran yang rumit.

Media pendidikan merupakan salah satu sumber belajar yang mendukung guru memperluas pengetahuan siswa. Berbagai macam bentuk dan jenis media pendidikan yang digunakan oleh guru dalam pembelajaran menjadi sumber ilmu pengetahuan bagi siswa. Dalam menjelaskan suatu benda, guru dapat membawa bendanya secara langsung kehadapan siswa di kelas. Dengan membawa bendanya bersamaan dengan penjelasan, maka benda tersebut dapat dijadikan sebagai sumber belajar. Dalam pembelajaran bahasa untuk anak-anak, efektifitas media pembelajaran harus benar-benar diperhatikan karena penguasaan bahasa mempunyai peran

${ }^{3}$ Tejo Nurseto, "Membuat Media Pembelajaran yang Menarik - Tejo Nurseto," Ekonomi \& Pendidikan 8 (2011): 19-35. 
penting dalam perkembangan anak dengan menggunakan bahasa anak akan berkembang menjadi manusia dewasa yang dapat bersosialisasi dengan orang-orang yang berada dilingkungannya. ${ }^{4}$ Salah satu media yang dapat membantu siswa dalam meningkatkan pembelajaran adalah Big book (Djamarah, Zain, 2010: 123).

Big Book adalah media berupa buku yang dibuat dalam ukuran besar untuk mengajarkan siswa belajar pengucapan kata, bentuk maupun jenis kata yang berisi gambar serta cerita singkat. Big Book juga merupakan media yang digunakan untuk meningkatkan minat baca anak. Big Book banyak disenangi anak-anak karena memiliki daya tarik tersendiri, seperti ukurannya yang besar, gambar yang berwarna warni, tulisan yang berukuran besar dan memiliki kalimat yang sederhana ${ }^{5}$.

Big Book adalah media cerita bergambar yang sesuai untuk kegiatan belajar di kelas. Buku cerita bergambar ini memilki ukuran dan isi yang besar disesuaikan dengan kebutuhan belajar siswa. Ada bermacam-macam gambar dan teks yang memiliki karakteristik warnawarni yang memungkinkan anak tertarik untuk membuka dan melihat isinya. Dengan menggunakan media Big Book, diharapkan siswa dapat lebih bersemangat mempelajari bahasa karena sebagaimana diketahui anak-anak cenderung lebih menyukai cerita bergambar. ${ }^{6}$ Sementara itu, ukuran tulisan pada big book yang cukup besar memungkinkan anak mudah membaca setiap kalimatnya. ${ }^{7}$

4 Akla, "Desain Pembelajaran Bahasa Arab berbasis Penanaman Karakter untuk Anak Usia Dini," Elementary: Jurnal Ilmiah Pendidikan Dasar 3, no. 2 (2017): $144-57$.

5 Aqila Darmata Synta, "Peningkatan keterampilan membaca permulaan melalui media," no. September (2015).

${ }^{6}$ Much Deniatur, "Pembelajaran Bahasa pada Anak Usia Dini Melalui Cerita Bergambar," Elementary: Jurnal Ilmiah Pendidikan Dasar 3, no. 2 (2017): 190-203.

${ }^{7}$ Putri Karlis Ramadhani dan Usep Kustiawan, "The Effect of the Big Book Media Usage to Simple
Buku bergambar merupakan media yang sangat baik untuk membangun sosial dan emosional siswa, membiasakan siswa untuk mengeluarkan pikiranyang ditemukan dari cerita tersebut. Melalui pembacaan cerita, anak dapat belajar lebih banyak tentang pengetahuan dan ketrampilan emosional dengan mudah. ${ }^{8}$

Hasil belajar adalah perubahan perilaku mahasiswa akibatbelajar. Perubahan perilaku disebabkan karena dia mencapai penguasaan atas sejumlah bahan yang diberikan dalam proses belajar mengajar. Pencapaian itu didasarkan atas tujuan pengajaran yang telah ditetapkan. Hasil itu dapat berupa perubahan dalam aspek kognitif, afektif maupun psikomotorik. ${ }^{9}$

Proses pembelajaran bahasa Arab yang berlangsung di MI Naelushibyan hanya menggunakan buku paket. Hal ini yang menyebabkan siswa kurang menyukai pelajaran bahasa Arab, karena pelajaran bahasa Arab adalah pelajaran yang sulit dipahamin dan bahasa nya yang asing sehingga pelajaran Bahasa Arab harus di buat semenarik mungkin agar siswa menyukai pelajaran bahasa arab.

Hasil belajar Bahasa Arab di MI Naelushibyan kelas IV masih rendah. Hal ini dapat dilihat dari rata-rata nilai yang masih di bawah KKM. Nilai KKM mata pelajaran bahasa arab yaitu 65. Sedangkan hasil belajar siswa MI Naelushibyan yang baik $15 \%$, cukup baik $35 \%$ dan yang kurang baik $50 \%$. Berdasarkan fakta yang peneliti lihat dilapangan terdapat beberapa masalah yaitu banyak siswa belum bisa mengaji (membaca tulisan arab), siswa kurang menyukai

Sentences' Reading Ability for Third Grader with Intellectual Disability on Elementary School for Special Needs," Journal of ICSAR 1, no. 1 (2017): 42-45.

8 Ivonne Hafidlatil Kiromi dan Puji Yanti Fauziah, "Pengembangan Media Pembelajaran Big Book untuk Pembentukan Karakter Anak Usia Dini," Jurnal Pendidikan dan Pemberdayaan Masyarakat 3, no. 1 (2016): 48-59.

9 Purwanto, Evaluasi Hasil Belajar. Yogyakarta: Pustaka Pelajar (Yogyakarta: Pustaka Setia, 2014), 46. 
pelajaran bahasa arab, pembelajaran yang berlangsung kurang menarik dan kurangnya respon siswa terhadap penjelasan guru.

Berdasarkan permasalahan tersebut, perlu adanya perbaikan dalam proses pembelajaran Bahasa Arab di kelas IV MI Naelushibyan dalam meningkatan hasil belajar siswa. Hal yang harus diperbaiki dalam proses pembelajaran Bahasa Arab yaitu dengan menggunakan media. Salah satu upaya untuk meningkatkan hasil belajar siswa pada mata pelajaran Bahasa Arab adalah dengan menggunakan media Big Book. Media Big Book selain untuk meningkatkan hasil belajar, juga digunakan sebagai daya tarik agar siswa tertarik dalam belajar Bahasa Arab, sehingga pada saat pembelajaran berlangsung siswa dapat memahami pelajaran tersebut.

\section{Metodologi}

Pendekatan dalam penelitian ini yaitu menggunakan penelitian kualitatif dan kuantitatif. Penelitian kualitatif adalah penelitian yang berlandaskan pada filsafat postpositivisme, digunakan untuk meneliti pada kondisi obyek yang alamiah, dimana peneliti adalah sebagai instrumen kunci, teknik pengumpulan data dilakukan secara triangulasi (gabungan), analisis data bersifat induktif/kualitatif, dan hasil penelitian kualitatif lebih menekankan makna dari pada generalisasi. ${ }^{10}$ Data yang diperoleh dari hasil penelitian ini adalah data hasil observasi yang sudah diolah berdasarkan rumus perhitungan nilai observasi.

Metode yang diterapkan dalam penelitian ini yaitu penelitian tindakan kelas (PTK). Penelitian tindakan kelas adalah penelitian yang dilakukan secara sistematis reflektif terhadap berbagai tindakan yang dlakukan oleh guru sekaligus sebagai peneliti, sejak disusunnya perencanaan sampai penilaian terhadap tindakan nyata

10 Sugiyono, Metode Penelitian Kuantitatif, Kualitatif, dan RED (Yogyakarta: Alfabet, 2015), 7. di dalam kelas berupa kegiatan belajar mengajar untuk memperbaiki kondisi pemelajaran yang dilakukan. Sementara itu, dilaksanakannya penelitian tindakan kelas untuk meningkatkan kualitas pendidikan atau pengajaran yang diselenggarakan guru/ peneliti di kelas. ${ }^{11}$

Jenis data merupakan identitas data penelitian yang dilakukan. Jenis data di bagi menjadi dua jenis yaitu data kuantitatif dan data kualitatif. Data kuantitatif pada penelitian ini berupa hasil belajar siswa pada mata pelajaran Bahasa Arab dengan menggunakan media Big Book yang diperoleh dari hasil tes setelah proses hasil belajar mengajar berlangsung. Adapun data kualitatif pada penelitian ini berupa lembar observasi aktivitas guru, lembar aktivitas siswa dan dokumentasi selama proses kegiatan belajar mengajar melalui media Big Book.

Sumber data dapat digolongkan kedalam sumber primer dan sumber sekunder. Sumber primer adalah sumber data pokok yang langsung dikumpulkan peneliti dari objek penelitian sedangkan data sekunder adalah data yang diperoleh peneliti dari sumber yang sudah ada. Adapun sumber data primer pada penelitian ini yaitu penelitian ini dilakukan di MI Naelushibyan kelas IV, dengan jumlah siswa sebanyak 15 siswa, yang terdiri dari 7 siswa laki-laki dan 8 siswa perempuan. Sedangkan sumber data sekunder pada penelitian ini yaitu terkait dengan perkembangan kelas seperti buku. absensi dan dokumentasi.

Teknik analisis lembar observasi digunakan untuk mengetahui peningkatan aktivitas belajar siswa pada tiap siklus dan akhir siklus dapat dilihat dari persentase ratarata aktivitas belajar siswa. Hasil yang dapat dihitung dalam menjumlahkan nilai seluruh siswa yang didapat untuk setiap aktivitas tersebut kemudian dihitung rata- ratanya.

${ }^{11}$ Anas Salahudin, Penelitian Tindakan Kelas (Bandung: Pustaka Setia, 2015), 26. 
Rata-rata aktivitas siwa/

$=\frac{\text { jumla } h \text { siswa sesuai indikator aktivitas siwa }}{\text { jumla } h \text { seluru } h \text { siswa }} \times 100 \%$

Rata-rata aktivitas guru

$=\frac{\text { skor hasil observasi guru }}{\text { skor total }} \times 100 \%$

Ketuntasan belajar secara individu ini digunakan untuk mengetahui siswa mana yang belum tuntas belajar di kelas IV MI Naelushibyan. Untukmenghitung persentase setiap nomor soal yang akan dicapai setiap siswa (Hayati, 2013:152).

dengan rumus:

$\frac{\text { jumlah ja waban yang benar }}{\text { jumlah soal }} \times 100 \%$

Untuk menentukan ketuntasan klasikal pada hasil belajar siswa dengan menggunakan rumus ketentuan klasikal

Ketentuan Klasikal =

$$
\frac{\text { Jumla h siswa } \geq 75 \%}{\text { Jumlah siswa }} \times 100 \%
$$

\section{Hasil dan Pembahasan}

\section{a. Deskripsi Hasil Evaluasi Belajar}

Pelaksanakan pembelajaran seharihari penelitihanya menggunakan metode ceramah dalam proses pembelajaran tanpa menggunakan media atau alat bantu yang lainnya. Proses pembelajaran seperti ini dapat menimbulkan kebosanan bagi siswa, karena selama proses pembelajaran lebih cenderung berpusat pada peneliti. Hal tersebut dapat berdampak terhadap nilai siswa yang rata-rata di bawah nilai KKM 65. Nilai rata-rata siswa yaitu 53.

Tabel 1

Nilai Hasil Belajar Siswa Pra Siklus

\begin{tabular}{|c|c|c|c|c|}
\hline No & $\begin{array}{c}\text { Jumlah } \\
\text { Siswa }\end{array}$ & $\begin{array}{c}\text { Jumlah } \\
\text { Nilai Siswa } \\
\text { Keseluruhan }\end{array}$ & KKM & $\begin{array}{c}\text { Nilai } \\
\text { Rata- } \\
\text { rata }\end{array}$ \\
\hline 1 & 15 & 795 & 65 & 53 \\
\hline
\end{tabular}

Berdasarkan tabel 1 dapat disimpulkan bahwa hasil belajar siswa sebelum menerapkan media Big Book masih rendah dengan hasil nilai rata-rata 53 sedangkan nilai KKM yang ditetapkan yaitu 65. Jumlah skor seluruh siswa pada pra siklus yaitu mencapai 795 .

Tabel 2

Nilai Hasil Belajar Siswa Siklus I

\begin{tabular}{|c|c|c|c|c|}
\hline No & $\begin{array}{c}\text { Jumlah } \\
\text { Siswa }\end{array}$ & $\begin{array}{c}\text { Jumlah } \\
\text { Nilai Siswa } \\
\text { Keseluruhan }\end{array}$ & KKM & $\begin{array}{c}\text { Nilai } \\
\text { Rata- } \\
\text { rata }\end{array}$ \\
\hline 1 & 15 & 1.155 & 65 & 77 \\
\hline
\end{tabular}

Berdasarkan tabel 2 dapat diketahui jumlah nilai hasil belajar siswa secara keseluruhan pada siklus I pada mata pelajaran bahasa arab dengan menerapkan media Big Book dengan jumlah siswa 15 orang yaitu 1.155, KKM yang ditetapkan adalah 65, dengan nilai rata-rata siswa yaitu 77 berada di atas nilai KKM, dengan kategori Baik.

Tabel 3

Nilai Hasil Belajar Siswa Siklus II

\begin{tabular}{|c|c|c|c|c|}
\hline NO & $\begin{array}{c}\text { Jumlah } \\
\text { Siswa }\end{array}$ & $\begin{array}{c}\text { Jumlah } \\
\text { Nilai Siswa } \\
\text { Keseluruhan }\end{array}$ & KKM & $\begin{array}{c}\text { Nilai } \\
\text { Rata- } \\
\text { rata }\end{array}$ \\
\hline 1 & 15 & 1.255 & 65 & 83,6 \\
\hline
\end{tabular}

Berdasarkan tabel 3 dapat diketahui jumlah nilai hasil belajar siswa secara keseluruhan pada siklus II pada mata pelajaran bahasa arab dengan menerapkan media Big Book dengan jumlah siswa 15 orang yaitu 1.255, KKM yang ditetapkan adalah 65 , dengan nilai rata-rata siswa 83,6 berada di atas nilai KKM, dengan kategori Sangat Baik.

\section{b. Deskripsi Hasil Observasi Aktivitas Guru dan Siswa}

Pengamatan terhadap aktivitas guru dan siswa dilakukan di setiap proses pembelajaran siklus I dan siklus II dengan masing-masing siklus dilaksanakan dua pertemuan. Dengan demikian dilakukan empat kali pengamatan pada masingmasing aktivitas guru dan siswa dalam 
pembelajaran. Adapun ringkasan analisis hasil pengamatan aktivitas guru dan aktivitas siswa ditunjukan pada tabel 4 .

Tabel 4.

Ringkasan Hasil Observasi Aktivitas Guru dan Siswa

\begin{tabular}{|c|c|c|c|c|}
\hline Observasi & \multicolumn{2}{|c|}{ Siklus I } & \multicolumn{2}{c|}{ Siklus II } \\
\cline { 2 - 5 } Aktivitas & $\begin{array}{c}\text { Tindakan } \\
\text { I }\end{array}$ & $\begin{array}{c}\text { Tindakan } \\
\text { II }\end{array}$ & $\begin{array}{c}\text { Tindakan } \\
\text { I }\end{array}$ & $\begin{array}{c}\text { Tindakan } \\
\text { II }\end{array}$ \\
\hline $\begin{array}{c}\text { Aktivitas } \\
\text { Guru }\end{array}$ & $66,6 \%$ & $72,2 \%$ & $88,8 \%$ & $94,4 \%$ \\
\hline $\begin{array}{c}\text { Aktivitas } \\
\text { Siswa }\end{array}$ & $63,67 \%$ & $69,21 \%$ & $82,09 \%$ & $91,07 \%$ \\
\hline
\end{tabular}

Hasil analisis padaTabel 4 menunjukan bahwa Aktivitas guru pada setiap siklusnya mengalami peningkatan. padasiklus I tindakan I diperoleh rata-rata $66,6 \%$, padasiklus I tindakan II diperoleh rata-rata $72,2 \%$, padasiklus II tindakan I diperoleh rata-rata $88,8 \%$ dan pada siklus II tindakan II diperoleh rata-rata $94,4 \%$.

Begitupun dengan aktivitas siswa dengan menerapkan media Big Book Aktivitas siwa pada setiap siklusnya mengalami peningkatan. Pada siklus I tindakan I diperoleh rata-rata $63,67 \%$, pada siklus I tindakan II diperoleh rata-rata $69,21 \%$, padasiklus II tindakan I diperoleh rata-rata $82,09 \%$ dan pada siklus II tindakan II diperoleh rata-rata $91,07 \%$.

\section{Pembahasan}

\section{Pra Siklus}

Sebelum diterapkan media Big Book pada proses pembelajaran, hasil belajar yang diperoleh siswa masih rendah, belum mencapai nilai kriteria ketuntasan minimum (KKM) yang ditetapkan disekolah. Nilai rata-rata siswa sebelum diterapkan media Big Book yaitu 53 masih di bawah nilai KKM yang ditetapkan. Hanya sekitar 33\% yang mencapai KKM.

Hal ini terlihat dari kegiatan siswa yang hanya mencatat dan mendengarkan apa yang disampaikan oleh guru. Sehingga siswa kurang memperhatikan guru ketika menyampaikan materipelajarandikarenakan guru tidak menggunakan media pada saat proses pembelajaran sehingga kurang menarikperhatiansiswa, guruhanyameminta siswa untuk menulis dan siswa membaca secara bersama-sama. Proses pembelajaran seperti ini dapat menimbulkan kebosanan bagi siswa dan kurangnya pemahaman siswa pada materi yang disampaikan oleh guru, karena selama pembelajaran berlangsung siswa hanya berpusat pada guru sehingga siswa cenderung bersifat pasif. Hal tersebut dapat berdampak pada nilai siswa yang ratarata masih dibawah nilai KKM.

Nikmah (2016) menyatakan bahwa pada proses pembelajaran guru belum melibatkan siswa secara aktif, guru belum memaksimalkan media pembelajaran, minat membaca siswa masih rendah, dan keterampilan membaca permulaan masih rendah. Penggunaan media buku besar(Big Book) dapat menjadi alternatif untuk menarik siswa mengikuti pelajaran, dan membuat siswa terlibat secara aktif dalam pembelajaran. Dijelaskan bahwa minat membaca siswa masih rendah karena siswa belum terbiasa untuk membaca dan meminjam buku di perpustakaan. Pada saat pembelajaran di kelas guru sering kali membacakan soal kepada siswa. Ini terjadi karena keterampilan membaca permulaan siswa rendah sehingga siswa kesulitan dalam mengerjakan soal yang diberikan oleh guru.

\section{Aktivitas Guru dan Siswa}

Pada siklus I, setelah melaksanakan kegiatan awal, guru melakukan beberapa kegiatan inti seperti:

a. Membuat prediksi

Guru mengajak siswa membaca bersama, meminta siswa mendengarkan, guru membacakan judul "usroti", kemudian meminta siswa untuk memprediksi isi cerita berdasarkan judul. Siswa diminta bercerita dengan temannya terkait judul, siswa membuat prediksi berdasarkan cover: latar dan tokoh. Guru memulai kegiatan membaca 
dan mengajak siswa untuk menerjemahkan cerita bersama-sama setelah membaca guru mencocokan prediksi dengan isi cerita yang berkaitan dengan latar dan tokoh.

b. Kata sulit dan tanda baca

Guru meminta siswa bercerita kembali qira'ah "usroti", guru membaca cerita dan siswa mendengarkan, guru menutup kata sulit yang terdapat dalam qira'ah, kemudian meminta siswa menjawab kata yang ditutupi dengan melihat gambar kemudian guru menjelaskan cara membaca ketika ada tanda baca (. , ! ?), guru membimbing siswa menemukan kata-kata sulit sulit pada qira'ah.

\section{c. Pemahaman}

Guru menanyakan pada siswa cerita yang telah dibaca, kemudian meminta beberapa siswa untuk bercerita, guru mengajak siswa untuk membaca qira'ah per kata dan memperhatikan tanda baca. Guru menanyakan profesi pada gambar dan meminta siswa mendeskripsikannya.

d. Merangkum

Guru menjelaskan tentang merangkum/meringkas kemudian guru mengeluarkan beberapa kartu (siapa, apa). Guru membuat rangkuman terkait jawaban dan siswa yang lainnya diminta untuk merangkai kata menjadi rangkuman yang baik.

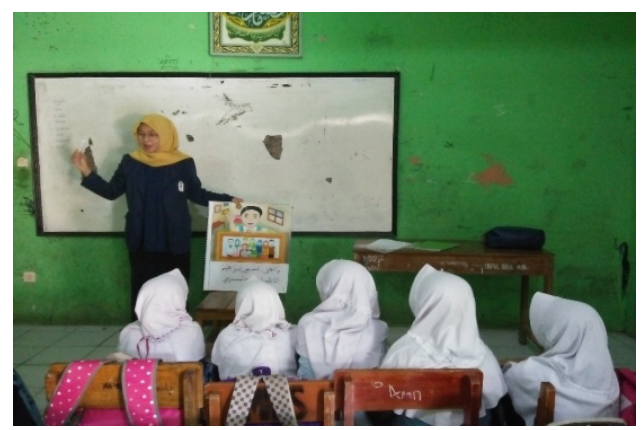

Gambar 1.

Guru dan Siswa Membaca Bersama

Guru dan siswa membaca bersama, guru membaca cerita 2-3 kata dan diikuti oleh semua siswa, kegiatan ini untuk mengetahui kemampuan membaca siswa.

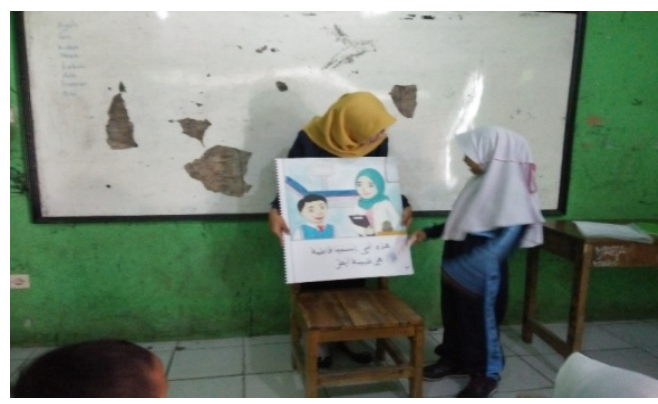

Gambar 2

Guru Menanyakan Profesi

Guru meminta siswa untuk maju kedepan dan meminta siswa untuk menyebutkan profesi yang ada di gambar menggunakan bahasa arab, kegiatan ini untuk mengetahui kemampuan siswa mengingat kosa kata. Setelah kegiatan inti selesai, maka guru melakukan kegiatan akhir. Peserta didik diminta untuk menyimpulkan pembelajaran yang telah berlangsung. Siswa merefleksi hasil proses belajar mengajar kemudian guru menutup kegiatan pembelajaran dengan mengucapan salam.

Berdasarkan hasil penelitian siklus I ternyata belum tercapai sehingga harus dilanjutkan sampai siklus II, adpaun beberapa kendala atau masalah yang perlu dicari pemecahan masalahnya agar penelitian di siklus II menjadi lebih baik lagi adalah sebagai berikut:

a. Guru belum terbiasa menciptakan suasana pembelajaran yang mengarah pada pembelajaran dengan menerapkan media Big Book. Hal ini diperoleh dari hasil observasi aktivitas guru dalam proses pembelajaran dengan mencapai rata-rata pada siklus I tindakan I yaitu $66,6 \%$ dan tindakan II yaitu $72,2 \%$ dengan interpretasi sedang.

b. Sebagian siswa belum terbiasa dengan kondisi belajar yang menerapkan media Big Book. Hal ini diperoleh dari hasil observasi aktivitas siswa dalam proses pembelajaran dengan rata-rata 
pada siklus I tindakan I yaitu 63,67\% dan tindakan II yaitu $69,21 \%$ dengan interpretasi sedang.

c. Masih ada siswa yang belum faham bagaimana media Big Book. Walau sudah sebagian besar siswa tuntas dan hanya 5 orang yang belum tuntas.

Untuk memecahkan masalah tersebut, maka peneliti melakukan beberapa tindakan sebagai berikut:

a. Guru harus menguasai tentang semua tahapan pembelajaran dengan menerapkan media Big Book.

b. Guru harus mampu memberikan motivasi kepada peserta didik dalam proses pembelajaran denganmenerapkan media Big Book.

C. Guru harus mampu mengkondisikan siswa saat pembelajaran.

Siklus II, seperti halnya siklus I, terdiri dari empat tahapan, yakni perencanaan dalam membuat RPP, tindakan dalam bentuk kegiatan-kegiatan inti yang sama, observasi dan refleksi. Pada tahapan observasi, diperoleh skor aktivitas siswa secara keseluruhan dengan julah siswa 15 orang diperoleh hasil observasi pada siklus II tindakan I yaitu 1.243,7, dengan rata-rata 14,93 dengan presentase yang diperoleh $82,9 \%$ berada pada kategori sangat baik.

Kemudian, pada tindakan kedua di siklus kedua, hasil observasi menunjukkan bahwa jumlah skor aktivitas siswa secara keseluruhan dengan jumlah siswa 15 orang diperoleh hasil observasi pada siklus II tindakan II yaitu 1.366,1 dengan rata-rata 16,4 dan jumlah presentase yang diperoleh yaitu 91,07\% berada pada kategori sangat baik.

Gambaran peningkatanhasilobservasi aktivitas siswa pada siklus I Tindakan I dan II, siklus II Tindakan I dan II adalah sebagai berikut:
Grafik 4.2

Peningkatan Aktivitas Siswa

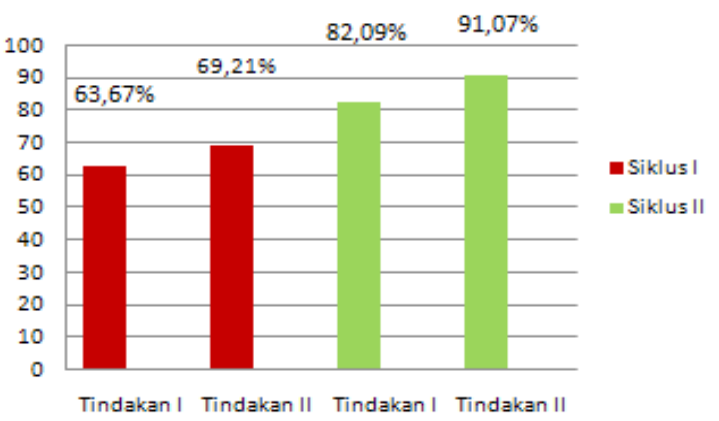

Berdasarkan grafik 4.2 dapat diketahui aktivitas siwa pada setiap siklusnya mengalami peningkatan. pada siklus I tindakan I diperoleh rata-rata $63,67 \%$, pada siklus I tindakan II diperoleh rata-rata $69,21 \%$, pada siklus II tindakan I diperoleh rata-rata $82,09 \%$ dan pada siklus II tindakan II diperoleh rata-rata $91,07 \%$.

Pada pembelajaran Bahasa Arab selama menggunakan media Big Book aktivitas guru dan aktivitas siswa mengalami peningkatan pada setiap siklusnya. Hal ini dapat dibuktikan dari skor yang didapatkan dari hasil observasi aktivitas guru dan aktivitas siswa pada siklus I dan siklus II.

Dengan menerapkan Big Book sebagai media pembelajaran pada mata pelajaran Bahasa Arab siswa cenderung lebih aktif dalam mengikuti proses pembelajaran dari awal hingga akhir dan guru lebih semangat dalam menyampaikan materi pembelajaran.

Synta (2015) memaparkan bahwa pembelajaran membacamenggunakan media Big Book mempengaruhi keaktifan siswa dan keterampilan siswa dalam membaca. Siswa menjadi semakin lancar dalam membaca dan lebih meningkat lagi dinilai dari beberapa aspek keterampilan membaca permulaan menggunakan media Big Book. Media Big Book dapat memperkaya perkembangan bahasa lisan anak menggunakan model membaca, dengan partisipasi tanpa resiko dalam melibatkan siswa untuk membaca dan berdiskusi dan membuatpembelajaran yang bermakna sesuai konteks. 
Berdasarkan analisis aktivitas siswa bahwa penerapan media Big Bookdapat meningkatkan kemampuan membaca siswa. Hal ini dapat dilihat dari hasil observasi aktivitas guru dan siswa yang meningkat disetiap siklusnya.

\section{Hasil Belajar}

Berdasarkan ketuntasan individual dan klasikal pada siklus I dapat disimpulkan bahwa perolehan rata-rata sebesar 77, sedangkan ketuntasan klasikal sebesar $66,6 \%$ dari seluruh siswa yang berjumlah 15 siswa. Artinya penelitian tindakan pada siklus I Masih dianggap kurang karena yang mencapai nilai KKM 65 hanya 10 siswa. Berdasarkan pembelajaran pada siklus II diperoleh nilai rata-rata sebesar 83,6. Kesimpulan dari penelitian tindakan kelas pada siklus II dapat dikatakan sudah sangat berhasil karena melebihi nilai KKM yang ditentukan yaitu 65 .

Terdapatnya perbedaan peningkatan hasil belajar siswa antara sebelum diterapkan media Big Book dan setelah diterapkan media Big Bookkarena kegiatan dalam proses pembelajaranyang dilakukan pada pra siklus, siklus I dan siklus II sangat berbeda. Akan tetapi peningkatan hasil belajar dari siklus I ke siklus II tidak sebanyak paningkatan hasil belajar dari pra siklus ke siklus I. Hal ini dikarenakan keterbatasan guru yang kurang maksimal dalam menyampaikan materi pembelajaran.

Mufidah (2017), berdasarkan deskripsi hasil penelitian dan pembahasan, maka dapat disimpukan bahwa pembelajaran dengan menggunakan media Big Book dapat meningkatkan kemampuan membaca pemahaman pada siswa kelas. Hal ini dapat dibuktikan dari peningkatan rata-rata nilai dan peningkatan kemampuan membaca siswa. Dengan diterapkan pembelajaran yang memanfaatkan media Big Book siswa menjadi lebih aktif dan antusias dalam mengikuti pembelajaran. Siswa juga lebih berani untuk bertanya. Guru juga berhasil menciptakan pembelajaran yang efektif dan menyenangkan.

Berdasarkan penelitian tersebut dapat disimpulkan bahwa media Big Book dapat meningkatkan hasil belajar dan dapat meningkatkan kemampuan membaca pemahaman. Hal ini dapat dibuktikan dari peningkatan rata-rata nilai yang diperoleh dari setiap siklusnya telah memenuhi KKM.

\section{Kesimpulan}

Berdasarkan analisis terhadap hasil penerapan media Big Book dalam meningkatkan hasil belajar siswa pada mata pelajaran Bahasa Arab materi ajar "Afrodul Usroti" diperoleh simpulan sebagai berikut:

1. Hasil belajar siswa sebelum menerapkan media Big Book diperoleh nilai rata-rata di bawah nilai kkm 65 yaitu 53. Hal ini dikarenakan guru kurang mampu mengembangkan pembelajaran dengan menerapkan media pembelajaran. Guru hanya menyuruh siswa menulis materi kemudian meminta siswa membaca qira'ah bersama-sama. dengan proses pembelajaran yang seperti itu dapat menimbulkan kebosanan pada siswa, karena dalam proses pembelajaran siswa lebih berpusat kepada guru.

2. Proses penerapan media Big Book dilihat dari aktivitas guru dalam proses pembelajaran berdasarkan dari hasil observasi selalu mengalami peningkatan yakni siklus I tindakan I 66,6\%, tindakan II $72,2 \%$ pada siklus II tindakan I $88,8 \%$, tindakan II 94,4\%.Demikian pula mengenai aktivitas siswa juga mengalami peningkatan. Hal ini terlihat dari keseluruhan rata-rata aktivitas siswa yakni siklus I tindakan I 63,67\% , tindakan II 69,21\% pada siklus II tindakan I 82,9\%, tindakan II 91,07\%.

Hasil belajar siswa setelahmenerapkan media Big Book pada setiap siklus selalu mengalami peningkatan. Hal ini terlihat 
dari hasil rata-rata belajar siswa pada pada siklus I sebesar 77 dengan kriteria baik dan siklus II 83,6 dengan kriteria sangat baik. Jadi dapat disimpulkan bahwa hasil belajar siswa mengalami peningkatan dalam setiap siklusnya.

\section{Daftar Pustaka}

Akla. "Desain Pembelajaran Bahasa Arab berbasis Penanaman Karakter untuk Anak Usia Dini." Elementary: Jurnal Ilmiah Pendidikan Dasar 3, no. 2 (2017).

Anas Salahudin. Penelitian Tindakan Kelas. Bandung: Pustaka Setia, 2015.

Andriani, Asna. "Pembelajaran Bahasa Arab" 03, no. September 2014 (2015): 39-56.

Ivonne Hafidlatil Kiromi, dan Puji Yanti Fauziah. "Pengembangan Media Pembelajaran Big Book untuk Pembentukan Karakter Anak Usia Dini." Jurnal Pendidikan dan Pemberdayaan Masyarakat 3, no. 1 (2016).

Much Deniatur. "Pembelajaran Bahasa pada Anak Usia Dini Melalui Cerita Bergambar." Elementary: Jurnal Ilmiah Pendidikan Dasar 3, no. 2 (2017).

Nurseto, Tejo. "Membuat Media Pembelajaran yang Menarik - Tejo Nurseto." Ekonomi \& Pendidikan 8 (2011): 19-35.

Purwanto. Evaluasi Hasil Belajar. Yogyakarta: Pustaka Pelajar. Yogyakarta: Pustaka Setia, 2014.

Ramadhani, Putri Karlis, dan Usep Kustiawan. "The Effect of the Big Book Media Usage to Simple Sentences' Reading Ability for Third Grader with Intellectual Disability on Elementary School for Special Needs." Journal of ICSAR 1, no. 1 (2017): 42-45.

Sugiyono. Metode Penelitian Kuantitatif,
Kualitatif, dan RED. Yogyakarta: Alfabet, 2015.

Synta, Aqila Darmata. "Peningkatan keterampilan membaca permulaan melalui media," no. September (2015). 